\title{
Pengaruh Struktur Modal dan Ukuran Perusahaan terhadap Nilai Perusahaan Asuransi di Indonesia
}

\author{
Christoforus Octavus dan I Gede Adiputra \\ Program Studi Manajemen Fakultas Ekonomi \& Bisnis \\ Universitas Tarumanagara \\ Email: pru.christoforus@gmail.com
}

\begin{abstract}
This research was conducted with the aim to find out whether there is an influence of Leverage (DER), Profitability Ratio (ROA), Firm Size (SIZE) on Firm Value (VALUE) Insurance Company in Indonesia. Population in this study are all the insurance company listed in Indonesian Stock Exchange in the period 2017 - 2019. The method of selecting samples used in this study is a non probability sampling method with a purposive sampling technique. The results of this study are Leverage that has a negative and non significant effect on Firm Value, Profitability Ratio has a positive and non significant effect on Firm Value, and Firm Size has a negative and significant effect on Firm Value.
\end{abstract}

Keywords : Capital Structure, Firm Size, Profitability Ratio, Debt to Equity Ratio, Firm Value

\begin{abstract}
Abstrak: Penelitian ini dilakukan dengan tujuan untuk mengetahui apakah terdapat pengaruh antara Rasio Hutang (DER), Rasio Profitabilitas (ROA), dan Ukuran Perusahaan (Firm Size) terhadap Nilai Perusahaan Asuransi di Indonesia. Populasi pada penelitian ini adalah seluruh perusahaan asuransi di Indonesia yang terdaftar di Bursa Efek Indonesia (BEI) pada periode 2017 - 2019. Metode pemilihan sample yang digunakan dalam penelitian ini adalah metode non profitability sampling dengan teknik purposive sampling. Hasil dari penelitian ini adalah Rasio Hutang (DER) berpengaruh negatif dan tidak signifikan terhadap Nilai Perusahaan, Rasio Profitabilitas berpengaruh positif dan tidak signifikan terhadap Nilai Perusahaan, Ukuran Perusahaan berpengaruh negatif dan signifikan terhadap Nilai Perusahaan.
\end{abstract}

Kata Kunci: Struktur Modal, Ukuran Perusahaan, Ratio Profitabilitas, Rasio Hutang terhadap Ekuitas, Nilai Perusahaan

\section{LATAR BELAKANG}

Seiring berkembangnya jaman, para manajer keuangan pastinya ingin selalu dapat mengembangkan struktur modal yang dimiliki oleh suatu perusahaan. Dengan adanya struktur modal yang baik, maka perusahaan dapat memiliki performa keuangan yang baik, serta kondisi perusahaan yang sehat. Tentunya, hal ini akan secara langsung berdampak pada kepuasan para pemegang saham, karena seharusnya nilai saham perusahaan dapat berkembang.

Pihak manajemen menghadapi tantangan yang tidak mudah, karena memiliki tanggung jawab yang sangat besar terhadap perusahaan, misalnya harus dapat meningkatkan nilai perusahaan, memiliki penempatan investasi yang baik, memastikan perusahaan memiliki cashflow yang baik, mengetahui behavior para investor, dan hal - hal lainnya yang tentu saja tidak mudah untuk dilakukan.

Modligiani dan Miller (1963) mencetuskan suatu teori bahwa perusahaan dapat memiliki komposisi struktur modal yang optimal sehingga dapat memperoleh penghematan pajak dan 
mengurangi risiko dari kebangkrutan. Untuk memperoleh struktur modal yang baik, semua bergantung pada bagaimana perusahaan melakukan strategi keuangannya.

Pihak manajemen dalam memenuhi kebutuhan dananya harus dapat pilihan sumber dana yang efisien dan menguntungkan perusahaan baik jangka pendek maupun untuk jangka panjang atau masa yang akan datang. Mengingat bahwa pilihan sumber dana tersebut akan berdampak pada kinerja perusahaan di masa yang akan datang, yaitu beban dana yang harus ditanggung perusahaan.

Berdasarkan uraian dan penjelasan permasalahan di atas, sangat penting mempertimbangkan faktor-faktor yang mempengaruhi nilai perusahaan, terutama dalam struktur modal yang dimiliki perusahaan. Dalam penelitian ini, penulis ingin mengidentifikasi struktur modal seperti apa yang sebaiknya dimiliki oleh perusahaan asuransi, sehingga dapat meningkatkan nilai perusahaannya.

\section{KAJIAN TEORI}

Pada tahun 1950-an, dua orang ekonom di dalam tulisannya yang berjudul "fundamental contributions to the theory of corporate finance" menentang pandangan pendekatan tradisional terhadap struktur modal. Mereka berpendapat bahwa sesungguhnya struktur modal tidak mempengaruhi nilai perusahaan. Teorema yang mereka berikan menjadi dasar pemikiran modern mengenai struktur modal.

Rasio Hutang. Menurut Kasmir (2010 : 156), rasio hutang merupakan rasio yang digunakan untuk mengukur perbandingan antara total utang dengan total aktiva. Dengan kata lain, seberapa besar aktiva perusahaan dibiayai oleh utang atau seberapa besar utang perusahaan berpengaruh terhadap pengelolaan aktiva.

Rasio Profitabilitas. Van Horne dan Wachowicz (2005 : 22) mengemukakan rasio profitabilitas terdiri atas dua jenis, yaitu rasio yang menunjukkan profitabilitas dalam kaitannya dengan penjualan dan rasio yang menunjukkan profitabilitas dalam kaitannya dengan investasi. Profitabilitas dalam hubungannya dengan penjualan terdiri atas margin laba kotor dan margin laba bersih. Profitabilitas dalam hubungannya dengan investasi terdiri atas tingkat pengembalian atas aktiva dan tingkat pengembalian atas ekuitas.

Ukuran Perusahaan. Menurut Sudarmadji dan Sularto (2017), ukuran perusahaan merupakan nilai yang menunjukkan besar kecilnya perusahaan. Menurut Suwito dan Herawaty (2015:138), ukuran perusahaan adalah suatu skala dimana dapat diklasifikasikan besar kecil perusahaan menurut berbagai cara, antara lain : total aktiva, log size, nilai pasar saham, dan lain - lain.

Nilai Perusahaan. Menurut Harmono (2009:233), Nilai Perusahaan adalah kinerja perusahaan yang dicerminkan oleh harga saham yang dibentuk oleh permintaan dan penawaran pasar modal yang merefleksikan penilaian masyarakat terhadap kinerja perusahaan.

Keterkaitan antara Rasio Hutang terhadap Nilai Perusahaan. Menurut penelitian yang dilakukan oleh Velnampy dan Niresh (2012), membuktikan bahwa struktur modal berpengaruh positif dan signifikan terhadap nilai perusahaan. Kusumajaya (2011) menjelaskan bahwa struktur modal mempunyai pengaruh positif dan signifkan terhadap nilai perusahaan. Penelitian yang dilakukan oleh Hirdinis M (2018) juga menyatakan bahwa struktur modal juga memiliki dampak positif yang signifikan terhadap nilai perusahaan. 
Keterkaitan antara Rasio Profitabilitas (ROA) terhadap Nilai Perusahaan. Pada penelitian yang dilakukan oleh Rina Dhaniati (2011), menunjukkan bahwa Return on Assets berpengaruh positif dan signifkan terhadap nilai perusahaan. Hal penelitian ini juga konsisten dengan penelitian yang dilakukan oleh Niken (2005) dan Novia (2010), bahwa laba berpengaruh positif terhadap rasio RBC. Menurut penelitian yang dilakukan oleh Hirdinis M, "profitability has no significant effect on firm value." Penelitian yang dilakukan oleh Hirdinis dengan mengambil sampel perusahaan sektor tambang yang terdaftar di IDX dengan menggunakan aplikasi SPSS 22.

Keterkaitan antara Ukuran Perusahaan terhadap Nilai Perusahaan. Penelitian yang dilakukan oleh Sunarto dan Budi (2014), menyatakan bahwa ukuran perusahaan berpengaruh positif terhadap nilai perusahaan. Hal ini sejalan dengan penelitian yang dilakukan oleh Obradovich dan Gill (2013), Purnomosidi (2014), dan Marius, dkk. (2014) menyatakan bahwa ukuran perusahaan berpengaruh positif terhadap nilai perusahaan. Menurut penelitian yang dilakukan oleh Setiadharma S dan Machali M, "there is no indirect effect of firm size on the firm value with the capital structure as intervening variable."

Berdasarkan uraian kaitan antar variabel di atas, maka terbentuklah kerangka pemikiran sebagai berikut :

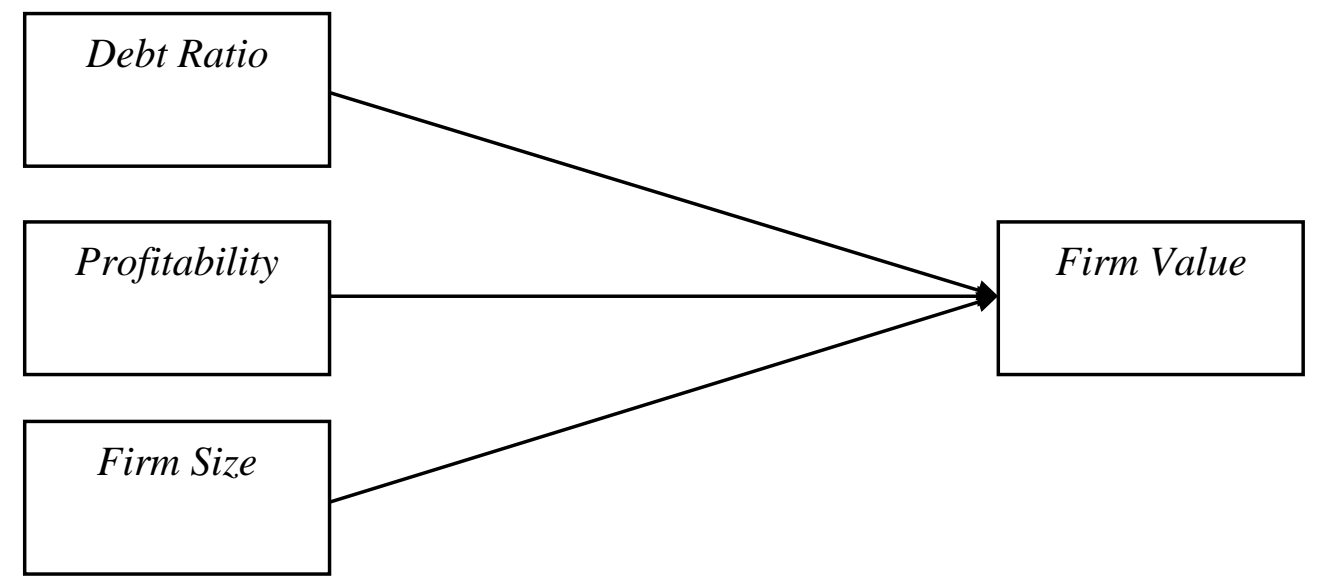

Gambar 1. Kerangka Pemikiran

H1 : Rasio Hutang tidak berpengaruh terhadap Nilai Perusahaan Asuransi

$\mathbf{H}_{2}$ : Rasio Hutang berpengaruh terhadap Nilai Perusahaan Asuransi

$\mathbf{H}_{3}$ : Rasio Profitabilitas tidak berpengaruh terhadap Nilai Perusahaan Asuransi

$\mathbf{H}_{4}$ : Rasio Profitabilitas berpengaruh terhadap Nilai Perusahaan Asuransi

H5 $_{5}$ : Ukuran Perusahaan tidak berperngaruh terhadap Nilai Perusahaan Asuransi

$\mathbf{H}_{6}$ : Ukuran Perusahaan berpengaruh terhadap Nilai Perusahaan Asuransi

\section{METODOLOGI}

Penulis melakukan penelitian ini menggunakan desain penelitian deskriptif dengan 3 variabel bebas dan 1 variabel terikat. Penelitian ini menggunakan penelitian asosiatif untuk mengetahui hubungan antara pengaruh debt ratio, profitability, dan firm size terhadap firm value pada perusahaan asuransi yang ada di Indonesia. Penelitian ini menggunakan jenis data kuantitatif yang dijabarkan dengan angka - angka. Data akan diuji dengan uji asumsi klasik (uji multikolinieritas) untuk mengetahui hubungan antara variabel dependen dengan variabel independent, dan diolah dengan menggunakan software Eviews 11. 
Penulis mengambil populasi yang digunakan dalam penelitian ini dari perusahaan asuransi yang terdaftar di Bursa Efek Indonesia (BEI). Data yang diambil dari periode tahun 2017 hingga 2019. Teknik pemilihan sampel yang dipilih oleh penulis adalah teknik purposive sampling. Penulis dalam melakukan penelitian ini menggunakan sampel pada perusahaan asuransi yang terdaftar di Bursa Efek Indonesia (BEI) sebanyak 9 perusahaan.

Berikut ini beberapa variabel yang diuji oleh penulis dan disertakan dalam bentuk tabel seperti di bawah ini :

Tabel 1. Variabel yang Diuji

\begin{tabular}{|c|c|c|}
\hline Variabel & Cara Pengukuran & Skala \\
\hline Nilai Perusahaan & $P B V=\frac{\text { Harga Pasar }}{\text { Nilai Buku Saham }}$ & Rasio \\
\hline Rasio Hutang & $D E R=\frac{\text { Total Debt }}{\text { Total Equity }}$ & Rasio \\
\hline Rasio Laba & ROA $=\frac{\text { Net Income }}{\text { Total Assets }}$ & Rasio \\
\hline Ukuran Perusahaan & Firm Size $=$ Total Assets & Rasio \\
\hline
\end{tabular}

Uji statistik yang dilakukan oleh penulis dalam penelitian ini adalah Uji Chow, Uji Hausman, Uji Lagrange Multiplier, Uji Multikolinieritas, dan Uji Koefisien Determinasi Berganda.

Pengolahan data proxy dalam penelitian ini menggunakan bantuan program computer yaitu Microsoft Excel 2019 dan Eviews 11 SV. Penelitian ini menggunakan model persamaan linier berganda sebagai berikut :

$$
Y_{i, t}=\alpha+\beta_{1} D E R_{i, t}+\beta_{2} R O A_{i, t}+\beta_{3} S I Z E_{i, t}+\varepsilon_{i, t}
$$

\section{HASIL UJI STATISTIK}

\section{a. Uji Statistik Deskriptif}

Tabel 2. Uji Statistik Deskriptif

Date: 07/01/20 Time: $21: 29$

Sample: 20172019

\begin{tabular}{lcccc}
\hline \hline & DER & ROA & SIZE & VALUE \\
\hline \hline Mean & 1.523697 & 2.827778 & $4.93 \mathrm{E}+12$ & 1.210917 \\
Median & 1.343930 & 3.393000 & $1.48 \mathrm{E}+12$ & 0.963380 \\
Maximum & 2.981310 & 27.64000 & $3.22 \mathrm{E}+13$ & 3.367450 \\
Minimum & 0.156450 & -19.82900 & $4.20 \mathrm{E}+11$ & 0.309720 \\
Std. Dev. & 0.842458 & 7.439730 & $9.29 \mathrm{E}+12$ & 0.877497 \\
Skewness & 0.041895 & 0.140143 & 2.409391 & 1.494602 \\
Kurtosis & 2.150041 & 8.762092 & 6.983720 & 4.225762 \\
& & & & \\
Jarque-Bera & 0.820632 & 37.44030 & 43.97703 & 11.74257 \\
Probability & 0.663441 & 0.000000 & 0.000000 & 0.002819 \\
& & & & \\
Sum & 41.13981 & 76.35000 & $1.33 \mathrm{E}+14$ & 32.69475 \\
Sum Sq. Dev. & 18.45312 & 1439.089 & $2.24 \mathrm{E}+27$ & 20.02003 \\
Observations & 27 & & & 27
\end{tabular}




\section{b. Uji Chow}

Tabel 3. Uji Chow

Redundant Fixed Effects Tests

Equation: Untitled

Test cross-section fixed effects

\begin{tabular}{lrrr}
\hline \hline Effects Test & Statistic & d.f. & Prob. \\
\hline \hline Cross-section F & 4.779810 & $(8,15)$ & 0.0045 \\
Cross-section Chi-square & 34.201744 & 8 & 0.0000 \\
\hline \hline
\end{tabular}

Dari hasil pengujian di atas, dapat kita lihat bersama bahwa hasil dari cross-section $F$ memiliki nilai di bawah 0.05 , sehingga dapat kita simpulkan bahwa $\mathrm{H}_{0}$ ditolak dan model yang tepat untuk digunakan dalam penelitian ini adalah fixed effect model.

\section{c. Uji Hausman}

Tabel 4. Uji Hausman

\begin{tabular}{|c|c|c|c|}
\hline Test Summary & Chi-Sq. Statistic & Chi-Sq. d.f. & Prob. \\
\hline Cross-section random & 0.937171 & 3 & 0.8164 \\
\hline
\end{tabular}

Dari hasil Uji Hausman, dapat disimpulkan bahwa model yang paling tepat digunakan dalam penelitian ini adalah random effect model.

\section{d. Uji Langrange Multiplier}

Tabel 5. Uji Langrange Multiplier

\begin{tabular}{|c|c|c|c|}
\hline & \multicolumn{3}{|c|}{ "Test Hypothesis } \\
\hline & Cross-section & Time & Both \\
\hline Breusch-Pagan & $\begin{array}{l}6.880868 \\
(0.0087)\end{array}$ & $\begin{array}{l}1.390626 \\
(0.2383)\end{array}$ & $\begin{array}{c}8.271494 \\
(0.0040)\end{array}$ \\
\hline Honda & $\begin{array}{c}2.623141 \\
(0.0044)\end{array}$ & $\begin{array}{c}-1.179248 \\
(0.8809)\end{array}$ & $\begin{array}{l}1.020986 \\
(0.1536)\end{array}$ \\
\hline King-Wu & $\begin{array}{c}2.623141 \\
(0.0044)\end{array}$ & $\begin{array}{c}-1.179248 \\
(0.8809)\end{array}$ & $\begin{array}{l}0.118353 \\
(0.4529)\end{array}$ \\
\hline Standardized Honda & $\begin{array}{l}3.608644 \\
(0.0002)\end{array}$ & $\begin{array}{c}-0.950920 \\
(0.8292)\end{array}$ & $\begin{array}{c}-1.266238 \\
(0.8973)\end{array}$ \\
\hline Standardized King-Wu & $\begin{array}{c}3.608644 \\
(0.0002)\end{array}$ & $\begin{array}{c}-0.950920 \\
(0.8292)\end{array}$ & $\begin{array}{c}-1.967608 \\
(0.9754)\end{array}$ \\
\hline Gourieroux, et al.* & -- & -- & $\begin{array}{c}6.880868 \\
(0.0124)\end{array}$ \\
\hline
\end{tabular}


Dari tabel di atas, dapat kita lihat bahwa nilai probabilitas chi-square di bawah dari 0.05. Sehingga dapat kita simpulkan bahwa $\mathrm{H}_{0}$ diterima sehingga model yang paling tepat digunakan dalam penelitian ini adalah fixed effect model.

\section{e. Uji Multikolinieritas}

Tabel 6. Uji Multikolinearitas

\begin{tabular}{crrrr}
\hline & \multicolumn{1}{c}{ DER } & \multicolumn{1}{c}{ ROA } & \multicolumn{1}{c}{ SIZE } & \multicolumn{1}{c}{ VALUE } \\
\hline \hline DER & 1.000000 & -0.174953 & -0.595488 & -0.046311 \\
ROA & -0.174953 & 1.000000 & 0.230598 & -0.067696 \\
SIZE & -0.595488 & 0.230598 & 1.000000 & -0.327579 \\
VALUE & -0.046311 & -0.067696 & -0.327579 & 1.000000
\end{tabular}

Dari hasil pengujian di atas, penulis mendapatkan beberapa kesimpulan yaitu : (1) DER dengan ROA tidak terjadi multikolinieritas, (2) DER dengan SIZE tidak terjadi multikolinieritas, (3) ROA dengan SIZE tidak terjadi multikolinieritas.

\section{DISKUSI DAN KESIMPULAN}

Berdasarkan penelitian yang dilakukan, penulis mendapatkan bahwa Rasio Hutang yang diproksikan dengan DER berpengaruh negatif dan tidak signifikan terhadap Nilai Perusahaan Asuransi di Indonesia yang diproksikan dengan PBV. Hal ini sejalan dengan penelitian yang dilakukan oleh Mamay Komarudin dan Naufal Affandi yang mendapatkan hasil yang serupa dengan penelitian yang dilakukan oleh penulis.

Berdasarkan penelitian yang dilakukan, penulis mendapatkan bahwa Rasio Profitabilitas yang diproksikan dengan ROA berpengaruh positif dan tidak signifikan terhadap Nilai Perusahaan Asuransi di Indonesia yang diproksikan dengan PBV. Hal ini sejalan dengan penelitian yang dilakukan oleh Setiadharma S dan Machail M yang mendapatkan hasil yang serupa dengan penelitian yang dilakukan oleh penulis.

Berdasarkan penelitian yang dilakukan, penulis mendapatkan bahwa Ukuran Perusahaan yang diproksikan dengan SIZE berpengaruh negatif dan signifikan terhadap Nilai Perusahaan Asuransi di Indonesia yang diproksikan dengan PBV. Hal ini sejalan dengan penelitian yang dilakukan oleh Hirdinis $\mathbf{M}$, bahwa penulis mendapatkan hasil yang sama dengan penelitian yang dilakukan.

\section{PENUTUP}

Penulis memahami bahwa penelitian yang sudah dilakukan memiliki keterbatasan dan mungkin terjadi ketidaktelitian atas sampel yang telah diteliti. Karena itu, penulis terbuka atas setiap saran yang diberikan dimana diharapkan dapat berguna dan bermanfaat untuk : (1) Bagi para peneliti, (2) Bagi Perusahaan, (3) Bagi para akademisi.

\section{DAFTAR PUSTAKA}

Aggrawal, Divya, and Padhan, Purna Chandra. (2017). Impact of Capital Structure on Firm Value : Evidence from Indian Hospitality Industry. Theoritical Economics Letters, 2017, 7, $982-1000$.

Chen, $\mathrm{Li}$ - Ju and Chen, Shun - Yu. (2011). The Influence of Profitability on Firm Value with Capital Structure as the moderator and Firm Size and Industry as moderators. Investment Management and Financial Innovations, 8(3). 
Gathogo, G., \& Ragui, D. M. (2014). The Company's Capital Structure Kenya : What Determines It? Research Journal of Finances and Accounting. 5(5).

Gultom, Margareta, Corry, dan Syarif, Firman. (2008). "Pengaruh Kebijakan Leverage, Kebijakan Dividen, dan Earnings per Share terhadap Nilai Perusahaan." Jurnal Akuntansi hal 47.

Harahap, S. (2006). Critical Analysis of Financial Statements ( $1^{\text {st }}$ ed). Jakarta : King Grafindo Persada.

Hirdinis. (2019). Capital Structure and Firm Size on Firm Value Moderated by Profitability. International Journal of Economics and Business Administration Volume VII, Issue I, 2019.

Komarudin, Mamay dan Naufal. (2019). Firm Value, Capital Structure, Profitability, Firm Charateristic and Disposable Income as Moderator : an Empirical Investigation of Retail Firms in Indonesia. Jurnal Inovasi Bisnis 7 (2019) $79-85$. www.ejournal.polbeng.ac.id/index.php/IBP.

Nyamasege D, Okibo WBA, Nyang'au AS, Sang'ania PO, Omosa H, et al. (2014). Effect of Asset Structure on Value of a Firm : A case of Companies Listed in Nairobi Securities Exchange. Research Journal of Finance and Accounting $5: 205-212$.

Purwohandoko. (2017). The Influence of Firm's Size, Growth, and Profitability on Firm Value with Capital Structure as the Mediator : A Study on the Agricultural Firms Listed in the Indonesian Stock Exchange. International Journal of Economics and Finance Vol 9, No. $8: 2017$.

Setiadharma dan Machail M. (2017). The Effect of Asset Structure and Firm Size on Firm Value with Capital Structure as Intervening Variable. Journal of Business \& Financial Affairs, 6(4).

Yudiatmadja, Fridayana. (2016). Pengaruh Struktur Modal dan Ukuran Perusahaan terhadap Nilai Perusahaan. e-journal Bisma Universitas Pendidikan Ganesha. Jurusan Manajemen. Vol 4. 